\title{
Analisis Kepuasan Pejabat Pembuat Komitmen Pada Pekerjaan Jalan Bidang Bina Marga Di Dinas Pekerjaan Umum Dan Penataan Ruang Kabupaten Ende
}

\author{
Mersiana Deti ${ }^{1}$, *Kristoforus $\mathrm{Je}^{2}$, Marselinus Yunior Nisanson ${ }^{3}$ \\ 1.2,3. Program Studi Teknik Sipil, Fakultas Teknik, Universitas Flores, Ende \\ *) Corresponce e-mail: jekristoforus@gmail.com
}

\begin{abstract}
ABSTRAK
Pejabat Pembuat Komitmen(PPK) adalah Salah satu penentu keberhasilan dan atau kepuasan sebuah proyek khususnya proyek rehabilitasi/pemeliharaan jalan dan jembatan pada Bidang Bina Marga Dinas Pekerjaan Umum dan Penataan Ruang Kabupaten Ende. Penelitian ini bertujuan untuk mengetahui Kepuasan Pejabat Pembuat Komitmen pada Pelaksanaan pekerjaan pembangunan jalan dan jembatan. dilihat dari aspek persiapan, perencanaan, pelaksanaan dan administrasi. Metode penelitian yang digunakan adalah metode Explanatory, dengan responden sebanyak 28 karyawan dan pengawas lapangan, teknik pengumpulan data berupa penyeberangan kuesioner. Hasil menunjukkan kepuasan Pejabat pembuat Komitmen pada proyek tersebut rata-rata kepuasan secara keseluruhan mendapat nilai sebesar 3,43 yang selanjutnya dinyatakan kotegori Puas dengan rentang nilai berkirar antara 60 -80\%, sedang kan hasil per aspek didapat sebagai berikut : aspek persiapan dengan nilai kepuasan 3,47 (kategori puas), aspek perencanan dengan nilai kepuasan 3,38 (kategori cukup puas), aspek pelaksanaan dengan nilai kepuasan 3,38 (kategori cukup puas), dan aspek administrasi dengan nilai kepuasan 3,49 (kategori puas). Hasil penelitian ini menunjukkan dari ke empat aspek diatas sangat mempengaruhi kepuasan Pejabat Pembuat Komitmen (PPK).
\end{abstract}

Kata Kunci: Persiapan,Perencanaan, Pelaksanaan, Administrasi, Kepuasan.

\section{PENDAHULUAN}

Kabupaten Ende dengan ibu kotanya Ende, adalah salah satu dari kabupaten yang terdapat di provinsi Nusa Tenggara Timur (NTT). Secara geografis, Kabupaten Ende terletak di tengah-tengah Pulau Flores dengan luas wilayahnya $2.046,60 \mathrm{Km}^{2}$ (204.660 ha), yang terdiri atas 21 kecamatan dengan jumlah penduduk 238.586 jiwa. Dalam pengembangan infrastruktur perkotaan maupun pedesaan, Kabupaten Ende lebih banyak menggunakan Dana Alokasi Umum (DAU), Dana Alokasi Kusus (DAK) dari pada dana Pendapatan Asli Daerah (PAD). Hal ini terjadi karena Pemerintah Kabupaten Ende belum bisa membiayai sendiri untuk membangun semua sektor pembangunan daerah dari dana Pendapatan Asli Daerah (PAD).

Pada tahun anggaran 2018 Pemerintah Kabupaten Ende melalui Dinas Pekerjaan Umum dan Penataan Ruang Kabupaten Ende, khususnya pada Bidang Bina Marga dengan program rehabilitasi/pemeliharaan pembangunan jalan dan jembatan, kegiatan rehablitasi /pemeliharaan jalan telah mengalokasikan dana sebesar Rp. 41.273.623.000,- untuk membiayai 5 ( lima) paket pekerjaan Rehabilitasi/ pemeliharaan jalan dan jembatan untuk lima penyedia jasa menang tender.

Dalam hal pembangunan fisik proyek, perlu membutuhkan tim kerja yang terstruktur baik dari pengguna jasa maupun penyedia jasa, harus memiliki sumber daya manusia yang berkomitmen tinggi dalam melaksanakan pekerjaan demi tercapainya hasil seta kepuasan maksimal dalam pengelolaan proyek tersebut.

Berdasarkan peraturan pemerintah nomor 45 tahun 2013 tetang tatacara pelaksanaan anggaran pendapatan dan belanja negara, maka pihak Pengguna Anggaran (PA), menunjukan seorang Pejabat Pembuatan Komitmen (PPK) yang memiliki wewenang penuh mengambil semua keputusan dan atau melakukan tindakan yang dapat mengakibatkan pengeluaran anggaran belanja negara maupun daerah. Sesuai dengan wewenang yang dimiliki PPK membentuk panitia pengelola kegiatan, menyusun spesifikasi, rancangan kontrak, tenaga administrasi, direksi lapangan, sedangkan pelaksana kegiatan adalah pihak kontraktor. 
Pejabat Pembuat Komitmen (PPK) memberikan syarat pekerjaan sesuai dengan spesifikasi, khusus pelaksanaan dalam bidang pembangunan sipil selalu dilihat dari proses perencanaan, pelaksanaan, spesifikasi pekerjaan, dan pelaporan.

Berdasarkan pengamatan lapangan terdapat beberapa item pekerjaan sudah mulai rusak retak -retak diantaranya HRS Base, timbunan pada bahu jalan yang tidak dipadatkan, serta pengawasan tidak melekat, keterlambatan pelaksanaan dari jadwal yang disediakan, tenaga tukang kurang terampil, perencanaan selalu berubah, lemahnya pengawasan, administrasi laorn sering terlambat.

Tujuan Penelitian untuk mengetahui Kepuasan Pejabat Pembuat Komitmen pada Pelaksanaan pekerjaan pembangunan jalan dan jembatan. dilihat dari aspek persiapan, perencanaan, pelaksanaan dan administrasi.

\section{Manajemen Konstruksi}

Dalam melaksanakan suatu pekerjaan, manajemen sangat diperlukan, baik dari aspek perencanaan, organisasi, pelaksanaan proyek konstruksi, pengawasan. Manajemen yang baik akan memberikan kelancaran dalam pelaksanaan sehingga mendapatkan hasil akhir sesuai sasaran yang diharapkan.

\section{Pengertian Manajemen Konstruksi}

Wulfram (2002), menyatakan manajemen adalah suatu proses/rangkaian kegiatan/kerja dan seorang pimpinan yang dilakukan dengan menggunakan cara pemikiran yang ilmiah maupun praktis untuk mencapai suatu tujuan yang telah ditetapkan dengan menentukan sumberdaya yang tersedia dengan cara setepat-tepatnya.

Teknologi konstruksi mempelajari metode atau teknik yang digunakan untuk mewujudkan bangunan fisik dalam lokasi proyek atau dapat diartikan sebagai uraian dari setiap langkah kegiatan (prosedur).

Manajemen Konstruksi adalah suatu rangkaian dengan melibatkan sumber daya dalam proyek konstruksi dapat diamplikasikan oleh manajer proyek secara tepat.

Proyek konstruksi merupakan suatu rangkaian kegiatan yang saling berkaitan untuk mencapai tujuan tertentu dalam batasan waktu, biaya dan mutu tertentu. Proyek konstruksi selalu memerlukan resources (sumber daya) yaitu man (manusia), material (bahan bangunan), machine (peralatan), method (metode pelaksanaan), money (uang), information (informasi), dan time (waktu).

\section{Unsur-Unsur Pembangunan Dalam Manajemen Konstruksi}

Usaha-usaha untuk mewujudkan sebuah pembangunan konstruksi, pihak-pihak yang terlibat dalam proyek konstruksi adalah sebagai berikut:

1. Pihak pemilik proyek (owner),

2. Pihak perencana (designer)

3. Pihak Kontraktor (aannemer)

\section{Pejabat Pembuatan Komitmen (PPK)}

Pejabat pembuatan komitmen yang selanjutnya disebut PPK adalah pejabat yang ditetapkan oleh panitia anggaran untuk melaksanakan pengadaan barang/jasa. Untuk ditetapkan sebagai pejabat pembuatan komitmen (PPK), harus memenuhi persyaratan sebagai berikut:

1. Memilki integritas,

2. Memiliki disiplin yang tinggi,

3. Memiliki tanggung jawab dan kualifikasi teknis serta manajerial untuk melaksanakan tugas, 
4. Mampu mengambil keputusan, bertindak tegas dan memiliki keteladanan dalam sikap perilaku serta tidak pernah terlibat korupsi, kolusi dan nepotisme (KKN),

5. Menanda-tangani fakta integritas,

6. Tidak menjabat sebagai pengelola keuangan,

7. Memiliki sertifikat keahlian pengadaan barang/jasa.

Kemampuan manajerial yang harus dimiliki oleh pejabat pembuat komitmen (PPK), antara lain harus memiliki syarat administrasi:

1. Pendidikan paling kurang sarjana dengan bidang keahlian yang sedapat mungkin sesuai dengan tuntutan pekerjaan.

2. Memiliki pengalaman paling kurang 2 (dua) tahun terlibat secara aktif dalam kegiatan yang berkaitan dengan pengadaan barang / jasa.

3. Memiliki kemampuan kerja secara berkelompok dalam melaksanakan setiap tugas / pekerjaan.

\section{Komitmen}

Pegawai merupakan sumber daya penting dalam keberhasilan suatu organisasi karena kegagalan seorang pegawai dalam melaksanakan tugasnya dan tanggung jawabnya, akan mempengaruhi proses pencapaian tujuan yang telah ditetapkan organisasi. Sebagai salah satu komponen yang penting pegawai harus memiliki komitmen yang kuat terhadap tugasnya karena pewagai harus memiliki kepedulian dan rasa tanggung jawab yang tinggi terhadap tugas-tugas yang diberikan. Hal ini didasari atas pemikiran bahwa keberhasilan pegawai untuk mencapai tujuannya menggambarkan keberhasilan organisasi secara keseluruhan.

\section{Kepuasan Kerja}

Handoko (2000), mengatakan kepuasan kerja adalah suatu keadaan pegawai dengan sikap senang atau tidak senang terhadap pekerjaan dan lingkungan tercermin dalam tindakan nyata melakukan pekerjaanya. Hasibuan (2008), menjelaskan kepuasan kerja adalah kondisi karyawan dalam keadaan menyenang dan mencintai pekerjaan, keadaan ini terlihat dalam kedisiplinan, dan prestasi kerja.

Robbins (2003), menjelaskan kepuasan kerja adalah sikap positif karyawan dalam menghadapi pekerjaan dengan sikap puas. Sedangkan sikap negatif karyawan menghadap pekerjaan dengan sikap tidak puas.

Berdasarkan uraian diatas maka dapat disimpulkan bahwa kepuasan kerja adalah kondisi karyawan terhadap beban kerja, kondisi kerja, hubungan antara karyawan, dan kebebasan dalam mengembangkan karir.

\section{Disiplin Kerja}

Poewadarminta (1989), Kamus Bahasa Indonesia, menjelaskan bahwa disiplin adalah ketaatan pada aturan dan tata tertib. Disiplin merupakan kemampuan melaksanakan dan mentaati tata cara yang telah ditentukan menurut norma-norma yang berlaku dalam pekerjaan sesuai dengan tugas dan tanggung jawabnya.

\section{Analisis}

\section{Uji Validitas dan Realibitas}

1. Validitas

Validitas adalah suatu ukuran yang menunjukkan tingkat kevalidan dan kesahan suatu instrumen. Suatu instrumen yang valid mempunyai validitas tinggi, sebaliknya instrumen yang kurang valid mempunyai produktivitas rendah. Sebuah instrumen dikatakan valid apabila mampu mengukur apa yang diinginkan.

Cara untuk menguji validitas dengan menggunakan rumus berikut ini: 


$$
\mathbf{r}=\frac{n \sum X Y-\left(\sum X\right)\left(\sum Y\right)}{\sqrt{\left(n \sum X^{2}-\left(\sum X\right)^{2}\right)\left(n \sum Y^{2}-\left(\sum Y\right)^{2}\right)}}
$$

Keterangan :

$\mathrm{r} \quad=$ Koefisien korelasi

$\mathrm{Y} \quad=$ Jumlah variabel bebas

$\mathrm{X} \quad=$ Elemen variabel bebas

$\mathrm{n} \quad=$ Jumlah data

Penyelesaian data nilai $\mathrm{r}_{\mathrm{XY}}$ dapat dilihat pada Tabel 2.1 berikut:

Tabel 2.1 Pedoman Untuk Memberikan Interprestasi Terhadap Koefisien Korelasi

\begin{tabular}{ll}
\hline Intervensi koefisien & Tingkat Hubungan \\
\hline $0,00-0,199$ & Sangat Rendah \\
$0,20-0,399$ & Rendah \\
$0,40-0,599$ & Sedang \\
$0,60-0,799$ & Kuat \\
$0,80-1,000$ & Sangat Kuat \\
\hline Sumber : (Sugiyono 2012) &
\end{tabular}

Selanjutnya untuk mencari makna hubungan variabel $\mathrm{X}$ dan $\mathrm{Y}$, maka korelasi $\mathrm{r}$ tersebut dihitung dengan uji-t dengan rumus:

$$
\begin{array}{ll}
\mathbf{t}_{\text {hitung }}=\frac{r \sqrt{n-2}}{\sqrt{1-r^{2}}} & \ldots \ldots \ldots \ldots \ldots \ldots \ldots \ldots \ldots \ldots \ldots . . . \ldots \ldots \\
\text { Dimana: } & =\text { nilai } \mathrm{t} \\
\mathrm{t}_{\text {hitung }} & =\text { nilai koefisien korelasi } \\
\mathrm{r} & =\text { nilai sampel } \\
\mathrm{n} &
\end{array}
$$

Suatu istrumen dinyatakan valid apabila harga koefisien $t_{\text {hitung }} \geq$.t.tabel untuk $\alpha=0,05$ dan derajat kebebasan $(d k=n-2)$. Jika $t_{\text {hitung }}>t_{\text {tabel }}$ berarti valid dan sebaliknya jika $t_{\text {hitung }}>t_{\text {tabel }}$ berarti tidak valid.

2. Reliabilitas

Pengukuran reliabilitas adalah pengukuran tentang stabilitas dan konsistensi dari alat pengukuran. Reabilitas menunjukkan pada suatu pengertian bahwa sesuatu instrument cukup dapat dipercaya untuk digunakan sebagai pengumpul data karena instrument tersebut sudah baik. Intrumen reliabilitas sebenarnya mengungkapkan data yang bisa dipercaya. Untuk mengukur reliabilitas dapat digunakan rumus Spearman Brown:

$$
\mathbf{r}_{\mathrm{i}}=\frac{2 \boldsymbol{r}_{\boldsymbol{b}}}{1+\boldsymbol{r}_{\boldsymbol{b}}}
$$

Keterangan:

$r_{i} \quad:$ Reliabilitas internal seluruh instrumen

$\mathrm{r}_{\mathrm{b}} \quad$ : Korelasi product momen antara belahan (ganjil-genap) atau (awal-akhir).

Syarat minimum untuk dianggap memenuhi syarat validitas adalah jika $r_{\text {hitung }}>r_{\text {tabel }}$ dan taraf signifikannya sebesar $5 \%$.

3. Analisis Prosentase

Dalam analisis penelitian ini digunakan untuk mengetahui dan menggambarkan keadaan tingkat kepuasan pada setiap variabel.

Rumus:

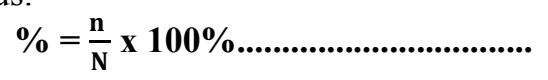

Dimana:

$\%=$ Tingkat Prosentase Kepuasan

$\mathrm{n}=$ Nilai yang diperoleh setiap item variabel

$\mathrm{N}=$ Nilai Total yang diperoleh setiap variabel 


\section{Tahap Penyusunan dan Penyebaran Kusioner}

Penyebaran kusioner dengan Proportionate Stratified random sampling teknik ini digunakan bila populasi mempunyai anggota/unsur yang tidak homongen dan berstrata secara proporsional. Skala nilai diuraikan pada Tabel 1. berikut ini :

Tabel 1. Skala Peringkat dan Nilai Kepuasan

\begin{tabular}{clcc}
\hline No & Penilaian Kepuasan & Skor Kepuasan & Nilai Skala Peringkat (\%) \\
\hline 1 & Tidak puas & 1 & $0-20$ \\
2 & Kurang puas & 2 & $21-40$ \\
3 & Cukup puas & 3 & $41-60$ \\
4 & Puas & 4 & $61-80$ \\
5 & Sangat puas & 5 & $81-100$ \\
\hline \multicolumn{2}{l}{ Sumber $:$ (Sugiyono 2012) }
\end{tabular}

\section{METODOLOGI PENELITIAN}

\section{Jenis Penelitian}

Dalam penelitian ini merupakan penelitian kuantitatif yaitu suatu metode dengan sistem pengambilan sampel dari suatu populasi dan melalui kuesioner terstruktur sebagai alat penggumpulan data.

\section{Analisa Data}

Data penelitian dikumpulkan dari hasil jawaban responden berupa pengisian kusioner, adapun pengisian kusioner dengan penilaian kepuasan diantaranya dapat dilihat pada tabel 2. berikut ini :

Tabel.2. Ukuran Jawaban responden

\begin{tabular}{llccc}
\hline No & Penilaian Kepuasan & Simbol & Skor Kepuasan & $\begin{array}{c}\text { Skor } \\
\text { Prosentase }\end{array}$ \\
\hline 1 & Tidak puas & TP & 1 & $0-20$ \\
2 & Kurang puas & KP & 2 & $20-40$ \\
3 & Cukup puas & CP & 3 & $40-60$ \\
4 & Puas & P & 4 & $60-80$ \\
5 & Sangat puas & SP & 5 & $80-100$ \\
\hline \multicolumn{2}{l}{ Sumber $:$ Sugiyono 2012) } & &
\end{tabular}

\section{Diagram Alir Penelitian}

Alur penelitian ini disusun sesuai dengan urutan pelaksanaanya dan dapat digambarkan pada gambar 1 . 


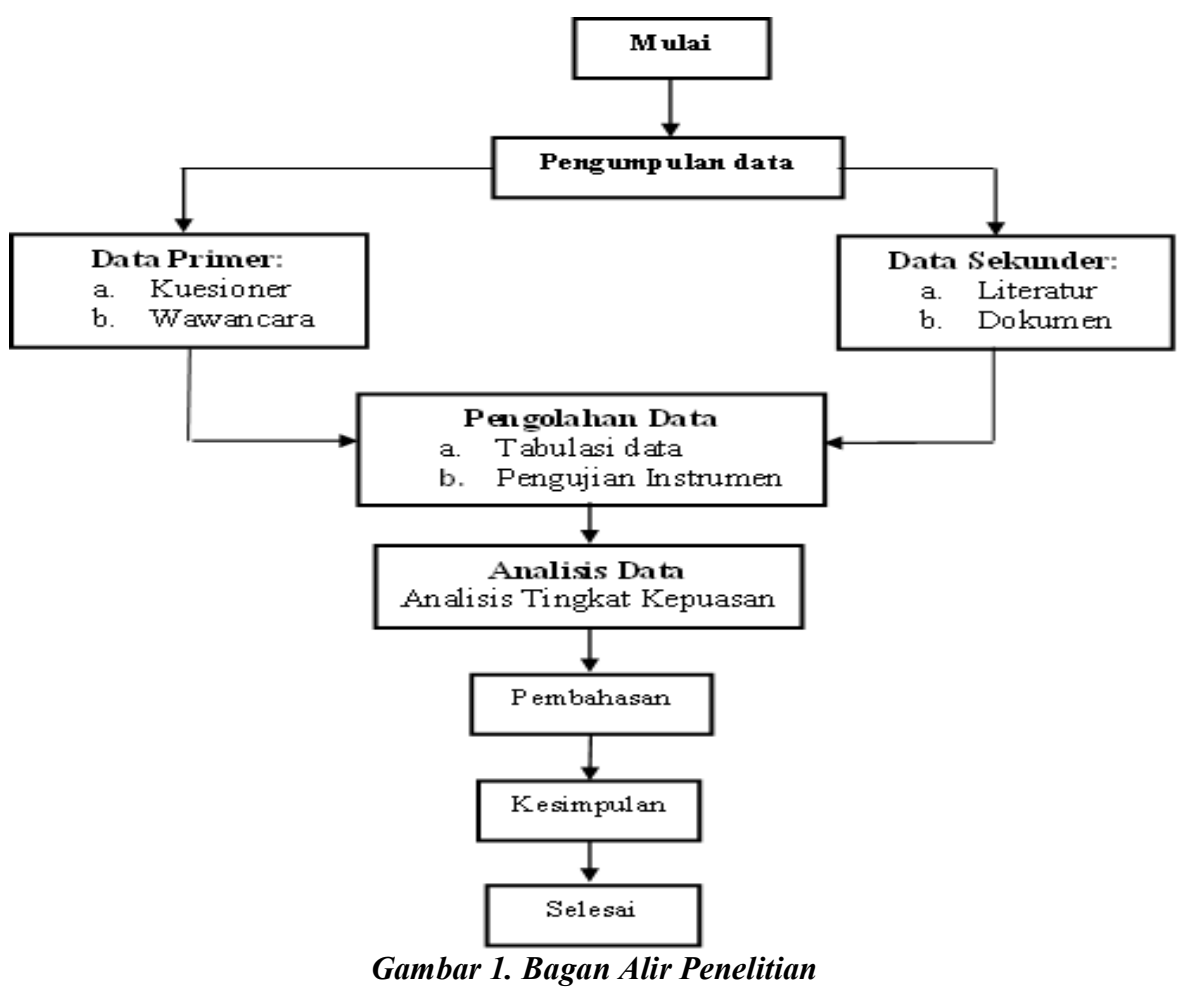

\section{HASIL DAN PEMBAHASAN}

\section{Uji Validitas}

Pengujian validitas untuk setiap variabel dapat dilihat pada tabel 3 . berikut ini :

Tabel 3. Pengujian Validitas

\begin{tabular}{|c|c|c|c|c|c|}
\hline No & $\begin{array}{c}\text { Koefisien } \\
\text { korelasi }\end{array}$ & $\begin{array}{c}\text { Harga t } \\
\text { hitung }\end{array}$ & $\underset{\substack{\text { Harga t } \\
\text { tabel }}}{\text { t }}$ & Keputusan & Kaidah Keputusan \\
\hline 1 & 0,4937 & 2,895 & 2,056 & Valid & $r \sqrt{n-2}$ \\
\hline 2 & 0,4522 & 2,528 & 2,056 & Valid & $\lg =\frac{\overline{\sqrt{1-r^{2}}}}{\sqrt{1}}$ \\
\hline 3 & 0,5103 & 3,026 & 2,056 & Valid & \\
\hline 4 & 0,5472 & 3,333 & 2,056 & Valid & $=0,4937 \sqrt{28-2}$ \\
\hline 5 & 0,5251 & 3,146 & 2,056 & Valid & $=\frac{\sqrt{1-0,4937^{2}}}{2}$ \\
\hline 6 & 0,5237 & 3,135 & 2,056 & Valid & $=2,895$ \\
\hline 7 & 0,4905 & 2,870 & 2,056 & Valid & distribusi t untuk $\alpha=$ \\
\hline 8 & 0,4568 & 2,618 & 2,056 & Valid & 0,05 \\
\hline 9 & 0,4924 & 2,885 & 2,056 & Valid & dan dua pihak dengan \\
\hline 10 & 0,4955 & 2,262 & 2,056 & Valid & derajad kebebasan \\
\hline 11 & 0,4955 & 2,909 & 2,056 & Valid & $(\mathrm{dk}=\mathrm{n}-2)$ \\
\hline 12 & 0,4689 & 2,707 & 2,056 & Valid & $t_{\text {hitung }} \geq \mathrm{t}$ tabelvalid \\
\hline 13 & 0,5510 & 3,367 & 2,056 & Valid & $\mathrm{t}$ hitung $\leq \mathrm{t}$ tabel tidak \\
\hline 14 & 0,5590 & 3,438 & 2,056 & Valid & valid \\
\hline
\end{tabular}

\section{Reabilitas}

Pengujian reliabel dapat dilihat pada tabel 4. dibawah ini: 
Tabel 4. Pengujian Reliabel

\begin{tabular}{|c|c|c|c|c|c|}
\hline No & $\begin{array}{c}\text { Koefisien } \\
\text { korelasi }\end{array}$ & $\begin{array}{c}\text { Harga } r_{i} \\
\text { hitung }\end{array}$ & $\begin{array}{c}\text { Harga } \mathbf{r}_{i} \\
\text { tabel }\end{array}$ & Keputusan & Kaidah Keputusan \\
\hline 1 & 0,4937 & 0,661 & 0,388 & Reliabel & $r_{i}=\frac{2 \cdot r_{b}}{}$ \\
\hline 2 & 0,4522 & 0,623 & 0,388 & Reliabel & $1_{1} \quad \overline{1+r_{b}}$ \\
\hline 3 & 0,5103 & 0,676 & 0,388 & Reliabel & \\
\hline 4 & 0,5472 & 0,707 & 0,388 & Reliabel & $r_{i}=\frac{2 \cdot(0,4937)}{200,661}$ \\
\hline 5 & 0,5251 & 0,689 & 0,388 & Reliabel & $1+0,4937$ \\
\hline 6 & 0,5237 & 0,687 & 0,388 & Reliabel & \\
\hline 7 & 0,4905 & 0,658 & 0,388 & Reliabel & $r$ product moment tarat \\
\hline 8 & 0,4568 & 0,627 & 0,388 & Reliabel & signifikannya sebesar \\
\hline 9 & 0,4924 & 0,660 & 0,388 & Reliabel & $1 \%$. \\
\hline 10 & 0,4955 & 0,577 & 0,388 & Reliabel & $r_{\text {hitung }} \geq \mathrm{r}$ tabel reliabel \\
\hline 11 & 0,4955 & 0,663 & 0,388 & Reliabel & $\mathrm{r}_{\text {hitung }} \leq \mathrm{r}$ tabel tidak \\
\hline 12 & 0,4689 & 0,638 & 0,388 & Reliabel & reliabel \\
\hline 13 & 0,5510 & 0,710 & 0,388 & Reliabel & \\
\hline 14 & 0,5590 & 0,717 & 0,388 & Reliabel & \\
\hline
\end{tabular}

\section{Tingkat Kepuasan Pekerjaan Persiapan, Perencanaan, Pelaksanaan, dan Administrasi}

Variabel kepuasan PPK pada pelaksanaan pekerjaan pembangunan turap/talud/bronjong, pembangunan saluran drainase/ gorong-gorong dan pembangunan infrastruktur jalan setapak, terdiri dari empat (4) variabel, diantaranya:

1) Variabel Persiapan:

a. Pihak penggunaan anggaran telah dibentuknya panitia penyediaan pengadaan langsung sesuai dengan syarat-syarat dan sesuai dengan kopetensi sumber daya manusia yang sesuai dengan pekerjaan.

b. Penunjukan pejabat (Ketua) penyediaan Pengadaan langsung sesuai dengan persyaratan dan pengalaman.

c. Demi melancarkan pekerjaan didukung oleh tenaga administrasi yang cukup baik

Tabel 5. Rata-rata Kepuasan pada variabel Persiapan.

\begin{tabular}{clc}
\hline No & \multicolumn{1}{c}{ Variabel Kepuasan } & Nilai Kepuasan \\
\hline 1 & Pembentuk panitia penyediaan pengadaan langsung & 3,53 \\
2 & Penunjukan pejabat (Ketua) penyediaan Pengadaan & 3,43 \\
& langsung & 3,46 \\
3 & Tenaga administrasi yang cukup baik & $\mathbf{1 0 , 4 2}$ \\
\hline$\sum$ & Jumlah Nilai Kepuasan & $\mathbf{3 , 4 7}$ \\
\hline
\end{tabular}

Tabel 5. di atas menggambarkan bahwa tingkat kepuasan pada persiapan pekerjaan penyediaan pengadaan langsung, mendapat nilai rata-rata kepuasan sebesar 3,47 termasuk dalam kategori puas berkisar antara $60-80 \%$.

2) Variabel Perencanaan

a. Telah melakukan survey lapangan untuk mendapatkan data guna memudahkan dalam perencanaan yang tepat

b. Gambar perencanaan telah sesuai dengan data survey sesuai dengan topografi yang ada

c. Penyusunan Spesifikasi sesuai dengan bangunan yang digunakan

d. Penetapan anggaran biaya sudah sesuai dengan volume pekerjaan

Tabel 6. Rata-rata Kepuasan pada variabel Perencanaan 


\begin{tabular}{clcc}
\hline No & \multicolumn{1}{c}{ Variabel Kepuasan } & Nilai Kepuasan \\
\hline 1 & $\begin{array}{l}\text { Melakukan survey lapangan untuk mendapatkan data guna } \\
\text { memudahkan dalam perencanaan yang tepat. }\end{array}$ & 3,43 \\
2 & $\begin{array}{l}\text { Perencanaan telah sesuai dengan data survey sesuai dengan } \\
\text { topografi yang ada }\end{array}$ & 3,32 \\
3 & $\begin{array}{l}\text { Penyusunan Spesifikasi sesuai dengan bangunan yang digunakan } \\
4\end{array} \quad \begin{array}{c}\text { Penetapan anggaran biaya sudah sesuai dengan volume pekerjaan } \\
\text { Jumlah Nilai Kepuasan }\end{array}$ & 3,25 \\
\hline$\sum$ & Rata-Rata $=\mathbf{1 3 , 5 0}: \mathbf{4}$
\end{tabular}

Tabel 6. di atas menggambarkan tingkat kepuasan perencanaan pekerjaan dan penyediaan pengadaan langsung, mendapat nilai rata-rata sebesar 3,38 termasuk dalam kategori cukup puas berkisar antara 40 $60 \%$.

3) Variabel Pelaksanaan

a. Kontraktor telah memenuhi persyaratan administrasi antara lain surat penawaran bermeterai, Biaya, Fakta Integritas, Dokumen penawaran teknis (metode kerja, Jadwal waktu pelaksanaan, daftar personil inti, Jenis kapasitas, komposisi dan jumlah peralatan minimum dilengkapi dengan bukti kepemilikan).

b. Kontraktor telah melengkapi dokumen penawaran: Fotocopy KTP direktur, Akte pendirian/akte perubahan, SBU, SIUJK, NPWP, SPT, Ijasah, SKT, KTP tenaga teknik, ijasah dan KTP tenaga administrasi.

c. Pengawasan teknis selalu aktif monitoring dan melakukan evaluasi secara bersama-sama secara periodik antara pengawas dan pelaksana (kontraktor).

d. Kontraktor telah menyelesaikan pekerjaan tepak waktu.

e. Hasil Pekerjaan bermanfaat bagi masyarakat pengguna jalan.

Tabel 7. Rata-rata Kepuasan variabel Pelaksanaan

\begin{tabular}{|c|c|c|}
\hline No & Variabel Kepuasan & Nilai Kepuasan \\
\hline 1 & $\begin{array}{l}\text { Pihak pelaksanaan (kontraktor), telah memenuhi } \\
\text { persyaratan administrasi seperti: surat penawaran } \\
\text { bermeterai, Biaya (lengkap), Fakta Integritas, } \\
\text { Dokumen penawaran teknis (metode kerja, Jadwal } \\
\text { waktu pelaksanaan, daftar personil inti, Jenis kapasitas, } \\
\text { komposisi dan jumlah peralatan minimum dilengkapi } \\
\text { dengan bukti kepemilikan). }\end{array}$ & 3,32 \\
\hline 2 & $\begin{array}{l}\text { Pihak pelaksanaan (kontraktor) telah melengkapi } \\
\text { dokumen penawaran: Fotocopy KTP direktur, Akte } \\
\text { pendirian / akte perubahan, SBU, SIUJK, NPWP, SPT, } \\
\text { Ijasah, SKT, KTP tenaga teknik, ijasah dan KTP } \\
\text { tenaga administrasi. }\end{array}$ & 3,46 \\
\hline 3 & $\begin{array}{l}\text { Pengawasan teknis selalu aktif monitoring dan } \\
\text { melakukan evaluasi secara bersama-sama secara } \\
\text { periodik antara pengawas dan Pelaksana (kontraktor). }\end{array}$ & 3,43 \\
\hline 4 & $\begin{array}{l}\text { Pihak Pelaksanaan telah menyelesaikan pekerjaan } \\
\text { tepak waktu }\end{array}$ & 3,32 \\
\hline 5 & $\begin{array}{l}\text { Hasil Pekerjaan bermanfaat bagi masyarakat yang } \\
\text { membeutuhkan }\end{array}$ & 3,36 \\
\hline$\sum$ & Jumlah Nilai Kepuasan & 16,89 \\
\hline Rat: & Rata $=16,89: 5$ & 3,38 \\
\hline
\end{tabular}

Tabel 7. di atas menggambarkan tingkat kepuasan pelaksanaan proses pengadaan langsung, mendapat nilai rata-rata sebesar 3,38 termasuk dalam kategori cukup puas berkisar antara $40-60 \%$. 


\section{Variabel Administrasi}

a. Laporan harian, mingguan dan bulanan tepat waktu.

b. Proses pencairan keuangan tepat waktu sesuai dengan kontrak

Tabel 8. Rata-rata Kepuasan pada variabel Administrasi

\begin{tabular}{llc}
\hline No & \multicolumn{1}{c}{ Variabel Kepuasan } & Nilai Kepuasan \\
\hline 1 & Laporan harian, mingguan dan bulanan Tepat waktu. & 3,43 \\
2 & Proses pencairan keuangan tepat waktu sesuai dengan & 3,54 \\
& kontrak & \\
\hline$\sum \quad$ Jumlah Nilai Kepuasan & $\mathbf{6 , 9 7}$ \\
Rata-Rata $=\mathbf{6 , 9 7 : 2}$ & $\mathbf{3 , 4 9}$ \\
\hline Hasil Analisis 2018
\end{tabular}

Tabel 8. di atas menggambarkan bahwa tingkat kepuasan ketepatan administrasi mendapat nilai sebesar 3,49 termasuk kategori puas berkisar antara $60-80 \%$.

\section{Rekapitulasi Kepuasan}

Rata-rata kepuasan pekerjaan dilihatdari aspek persiapan, perencanaan,pelaksanaan serta administrasi dapat dilihat pada tabel 9.

Pada Tabel 9. di bawah ini juga menggambarkan bahwa tingkat kepuasan secara keseluruan, dari tahap persiapan, tahap perencanaan, tahap pelaksanaan dan tahap administrasi mendapat nilai kepuasan sebesar 3,43 termasuk dalam kategori cukup puas.

Tabel 9. Rata-rata Kepuasan Pekerjaan Secara Keseluruan.

\begin{tabular}{llc}
\hline No & \multicolumn{1}{c}{ Variabel Kepuasan } & Nilai Kepuasan \\
\hline 1 & Tahap Persiapan & 3,47 \\
2 & Tahap Perencanaan & 3,38 \\
3 & Tahap Pelaksanaan & 3,38 \\
4 & Tahan Administrasi & 3,49 \\
\hline$\sum$ & Jumlah Nilai Kepuasan Secara keseluruan & $\mathbf{1 3 , 7 2}$ \\
Rata-Rata $=\mathbf{1 3 , 7 2}: \mathbf{4}$ & $\mathbf{3 , 4 3}$ \\
\hline Hasil & Analisis 2018
\end{tabular}

Sebagai responden hanya panitia, pengawas lapangan pada program Rehabilitasi/Pemeliharaan jalan dan jembatan pada Dinas Pekerjaan Umum dan Penataan Ruang Bidang Bina Marga Kabupaten Ende dengan jumlah reponden sebanyah 28 responden pada pekerjaan 5 Paket jalan dan jembatan menunjukkan tingkat kepuasan pihak PPK (Pejabat Pembuat Komitmen), sebagai berikut:

Kepuasan secara keseluruan mulai dari persiapan, perencanaan, pelaksanaan, dan administrasi mendapat nilai kepuasan sebesar 3,43 atau dalam kategori cukup puas, dengan rincian sebagai berikut:

1) Pada pekerjaan persiapan mendapat nilai kepuasan sebesar 3,47 atau dalam kategori puas

2) Pada pekerjaan perencanaan mendapat nilai kepuasan sebesar 3,38 atau dalam kategori cukup puas

3) Pada pekerjaan pelaksanaan mendapat nilai kepuasan sebesar 3,38 atau dalam kategori cukup puas

4) Pada pekerjaan administrasi mendapat nilai kepuasan sebesar 3,49 atau dalam kategori puas.

\section{KESIMPULAN}

Berdasarkan hasil penilitian dari pihak PPK sesuai kepuasan secara keseluruan mulai dari persiapan, perencanaan, pelaksanaan, dan administrasi mendapat nilai kepuasan sebesar 3,43 (40 - 60\%), berada dalam kategori cukup puas, dengan rincian sebagai berikut:

1) Aspek persiapan mendapat nilai kepuasan sebesar 3,47 (60 - 80\%), berada dalam kategori puas. 
2) Aspek perencanaan mendapat nilai kepuasan sebesar 3,38 (40 - 60\%), berada dalam kategori cukup puas.

3) Aspek pelaksanaan mendapat nilai kepuasan sebesar 3,38 (40 - 60\%), berada dalam kategori cukup puas.

4) Aspek administrasi mendapat nilai kepuasan sebesar 3,49 (60 - 80\%), berada dalam kategori puas.

\section{DAFTAR PUSTAKA}

Ervianto, Wulfram. I. 2002. Manajemen Proyek Konstruksi. Edisi Pertama, Salemba Empat. Yogyakarta. Handoko, T. Hani. 2000. Manajemen. Edisi 2. Yogyakarta: BPFE.

Handoko, T. Hani. 2001. Manajemen Personalia dan Sumberdaya Manusia. Yogyakarta: BPFE. Hasibuan, Malayu. S.P. 2008. Manajemen Sumber Daya manusia. Jakarta: Bumi Angkasa.

Jasin, A. 1989. Peningkatan Pembinaan Disiplin Nasional dalam Sistim dan Pola Pendidikan Nasional. Jakarta.

Kanter, R.M. 1986. The Art of Innovation: How To Be Achange Master. Nightingle Conant. Luthans, Fred. S. 1995. Organizational Behavior, Seventh Edition. Singapore.

Mowday. R.T, L.W. Porter, dan Steers. R.M. 1989. Employee-Organisation Linkages: The Psychology of Commitment. Absenteeism and Turnover. New York: Academic Press.

Poerwadaminta, WJS. 1989. Kamus Umum Bahasa Indonesia. Jakarta: Balai Pustaka.

Siagian, S.P. 2008. Manajemen Sumber Daya manusia. Jakarta: Bumi Aksara.

Sugiyono. 2012. Metode Penelitian Kuantitatif dan R\&D. Bandung: Alfabeta.

Sopiah. 2008. Perilaku Organisasi. Yogyakarta: Andi Offset. 